\title{
Correlation of anthropometric parameters with lipid profile in first year medical students
}

\author{
Jagruti Dholakia ${ }^{1, *}$, Hariom Sharma ${ }^{2},{\text { Smita N } \text { Vasava }^{3} \text {, Subhankar Kayal }}^{4}$ \\ ${ }^{1,3}$ Tutor, ${ }^{2}$ Professor and Head, ${ }^{4}$ P.G. Student, Dept. of Biochemistry, Govt. Medical College, Bhavnagar, Gujarat, \\ India
}

*Corresponding Author:

Email: gajjar1968@yahoo.co.in

\begin{abstract}
Introduction: Lifestyle related risk factors are prone to increase the burden of cardiovascular diseases. Thus, the study was carried out in the medical students who are more prone to develop lifestyle diseases because of their busy schedule and less time for extracurricular activities.

Objective: To study correlation of anthropometric and biochemical parameters in first year medical students.

Materials and Methods: Total 150 students of first year MBBS (Batch 2014-2015) Government Medical College (GMC), Bhavnagar were enrolled in the study. Anthropometric measurements were carried out to measure body weight (BW), body height (BH), Waist circumference (WC) and hip circumference (HC), while Body mass index (BMI) was calculated. Blood samples were collected for estimation of fasting blood glucose (FBS), Lipid profile, Total protein and Albumin. The investigations were performed on fully auto analyzer I-Lab 650, in Clinical Biochemistry Laboratory, Sir T. Hospital, Bhavanagar.

Results: Results concluded that 1) Overweight and obesity among the students were $17.3 \%$ and $4 \%$ respectively; 2) When the abnormal serum cholesterol $(\geq 200 \mathrm{mg} \%$ ) was compared between male and female students it was statistically significant with p $0.003 ; 3)$ In the present study $03(2.0 \%)$ students had FBS $>126 \mathrm{mg} / \mathrm{dl}$, high risk of developing Type 2 diabetes mellitus. 4) In the present study WC showed positive correlation with blood pressure, r: -0.28 and p: 0.0005 and negative correlation with HDL-Cholesterol, $r:-0.21$ and p: 0.008 . Whereas, BMI showed positive correlation with triglyceride with $\mathrm{r}:-0.27$ and p: 0.0008 and negative correlation with HDLCholesterol with $\mathrm{r}:-0.34$ and $\mathrm{p}<0.0008$ considered highly significant.

Conclusion: High prevalence of cardiovascular risk factors like overweight, high blood pressure and high triglyceride were common among the medical students. So, it can be concluded that healthy lifestyles should be adopted from young adulthood since medical students are the future health providers.
\end{abstract}

Keywords: Medical students, cardiovascular disorders, lipid profile, nutritious food.

Received: $05^{\text {th }}$ July, 2017

\section{Introduction}

With growing urbanization and effect of Westernization, in India there has been an increase in lifestyle disorders. These disorders affect the younger age groups and adolescents at an increasing rate. Physical inactivity, stress on technology, increase use of computers and alarming consumption of junk food in the childhood has led to an increase in the lifestyle disorders at an alarming rate. ${ }^{1}$

Lifestyle disorders are responsible for the development of various metabolic diseases such as hypertension, diabetes, hypercholesterolemia, overweight and obesity. Meanwhile, it is well established that healthy practices, such as weight management, physical recreational activity and sleeping habits, have an impact on the health of the individuals. At least $80 \%$ of heart disease, stroke and type 2 diabetes, as well as $40 \%$ of cancer could be avoided by healthy diet, regular physical activity and avoid use of tobacco. ${ }^{2}$
Accepted: $05^{\text {th }}$ October, 2017

Good health is important for all and especially to medical students and healthcare personnel who should be role models in terms of health consciousness and sound life style practices. If the medical students are sensitized early in their courses, it will help them to make healthy choices for themselves, which will also empower them to act as facilitators in influencing community to adopt healthy lifestyles. ${ }^{3}$

While medical school lays a firm foundation for the essential knowledge, physicians must possess, it should also inculcate and promote the ideal characteristics of compassion, integrity, empathy, professionalism, and commitment to service and lifelong learning. These qualities will flourish when they receive nourishment from solid mental health. ${ }^{4}$

With this background, the present study was undertaken in the first year medical students (Batch 2014-2015) of Govt. Medical College, Bhavnagar to find out the changes in anthropometric and biochemical factors. 


\section{Materials and Methods}

The present study was conducted in the department of Biochemistry, Government Medical College and Sir Takhtsinhji General Hospital, Bhavnagar. Ethical clearance was taken from the institute. In the study, 150 students of first year MBBS were included. The students who signed the informed consent and who met the inclusion criteria were included in the study. They were divided according to the gender.

\section{Inclusion criteria}

1. Students above the age of 17 years.

2. Both male and female students of $1^{\text {st }}$ MBBS.

3. Student who is able to give informed and written consent.

\section{Exclusion criteria}

1. Student, not willing to give informed consent.

2. Acutely ill student

\section{Physiological Parameters}

Anthropometric measurements were carried out with a digital scale to measure body weight (BW), body height (BH) was measured by using a commercial stadiometer. Body mass index (BMI) was calculated as $\mathrm{BW}$ in $\mathrm{kg}$ divided by the square of the $\mathrm{BH}$ in meters $\left(\mathrm{m}^{2}\right)$. Waist circumference (WC) was measured at the highest point of iliac crest at the level of umbilicus and hip circumference (HC) at the fullest point around the buttocks. Waist and hip ratio was calculated. Blood pressure (BP) was measured using mercury sphygmomanometer in right upper arm in supine position after five minutes of rest.

\section{Laboratory Investigations}

Biochemical investigations were carried out after overnight fasting of twelve hours. Fasting blood samples were collected in plain and fluoride vaccuttes. Biochemical parameters like Fasting Blood Sugar (FBS), Lipid profile and Total protein and Albumin were analyzed on fully auto analyzer I-Lab 650 in Clinical Biochemistry Section, Sir. Takhtsinhji, General Hospital, Bhavnagar.

Glucose was estimated by GOD-POD method. Total cholesterol estimation by CHOD PAP method. Triglyceride estimation by GPO PAP method. HDL-cholesterol estimation by direct method. LDL-cholesterol estimation by direct method. Total protein was estimated by Biuret method and Albumin was estimated by BCG method.

Students were given to fill a questionnaire about past illness, family history, dietary habits and physical activities.

\section{Statistical Analysis}

Categorical data was expressed as percentage. Whereas numerical data was expressed as Mean \pm S.D. Anthropometric and Biochemical parameters between male and female students were compared using unpaired $t$ test.

Categorical data between male and female students were compared using chi square test. Correlation between anthropometric parameters with blood pressure and lipid parameters were done by calculating Pearson's Correlation coefficient.

$\mathrm{p}=0.05$ was considered as statistically significant. All these statistical calculations were done using Graph pad.

\section{Results}

\section{Demographic details}

Out of 150 students, males were $52.67 \%$ and females were $47.33 \%$ (Table 1). Mean age of male students was 18.6 years and female students was 17.8 years. Out of 150 students, 125 students were residing in the hostel whereas 25 students were localites.

\section{Table 1: Distribution of the students} according to gender

\begin{tabular}{|l|c|c|}
\hline \multicolumn{1}{|c|}{ Students } & Number & Percentage \\
\hline Male Students & 79 & 52.67 \\
\hline Females Students & 71 & 47.33 \\
\hline Total & 150 & 100 \\
\hline
\end{tabular}

\section{Anthropometric parameters}

According to WHO body weight classification for Asian population, in our study we found that (22)27.8\% male students and (27)38.0 \% female students had BMI <18.5 (underweight). (39)54.9\% males and (62) $42.2 \%$ females had BMI 18.5-22.9 (normal weight). (14) $17.7 \%$ males and (12)16.9\% females had BMI 23.0-27.4 (Overweight) while (04)5.6\% males and (02)2.8\% females had BMI $\geq 27.5$ (Obese) table 2. Average height and weight among the male and female students was statistically significant with $\mathrm{p}<0.001$. Waist circumference (WC) in males was $31.50 \pm 3.02$ and females was $30.02 \pm 3.05$ with p: 0.003 considered significant, hip circumference (HC) in males was $37.15 \pm 2.44$ and females was $35.84 \pm 2.89$ with p: 0.003 considered significant, BMI in males was $20.86 \pm 3.77$ and females was $20.11 \pm 3.40$ with p: 0.20 not statistically significant and waist/hip ratio in males was $0.85 \pm 0.07$ and females was $0.86 \pm$ 0.06 with $\mathrm{p}: 0.35$ was not statistically significant. (Table 3). 
Table 2: Classification of BMI of the students according to WHO guidelines for Asian population

\begin{tabular}{|l|c|c|c|c|c|c|}
\hline \multirow{2}{*}{ BMI in kg/m2 } & \multicolumn{2}{|c|}{ Male (n=79) } & \multicolumn{2}{c|}{ Female (n=71) } & \multicolumn{2}{c|}{ Total students(n=150) } \\
\cline { 2 - 7 } & $\begin{array}{c}\text { No. of } \\
\text { Students }\end{array}$ & Percentage & $\begin{array}{c}\text { No. of } \\
\text { Students }\end{array}$ & Percentage & $\begin{array}{c}\text { No. of } \\
\text { Students }\end{array}$ & Percentage \\
\hline $\begin{array}{l}\mathbf{1} \text { 18·5 } \\
\text { (underweight) }\end{array}$ & 22 & 27.8 & 27 & 38.0 & 47 & 31.3 \\
\hline $\begin{array}{l}\mathbf{1 8 \cdot 5 - 2 2 . 9} \text { (Normal } \\
\text { weight) }\end{array}$ & 39 & 54.9 & 30 & 42.2 & 69 & 46 \\
\hline $\begin{array}{l}\mathbf{2 3 . 0 - 2 7 . 4} \\
\text { Overweight) }\end{array}$ & 14 & 17.7 & 12 & 16.9 & 26 & 17.3 \\
\hline$\geq 27.5$ (Obese) & 04 & 5.6 & 02 & 2.8 & 06 & 4 \\
\hline
\end{tabular}

Table 3: Distribution of Anthropometric and lab parameters among study subjects

\begin{tabular}{|l|c|c|c|c|}
\hline $\begin{array}{c}\text { Clinical/Lab/Anthropomet } \\
\text { ric measures }\end{array}$ & $\begin{array}{c}\text { Mean ( SD) } \\
\text { n=150 }\end{array}$ & Males n=79 & Females n=71 & P-value \\
\hline Height(cm) & $163.88 \pm 9.00$ & $170.01 \pm 6.45$ & $157.05 \pm 6.06$ & $<0.0001$ \\
\hline Weight (kg) & $55.37 \pm 12.13$ & $60.40 \pm 12.06$ & $49.76 \pm 9.52$ & $<0.0001$ \\
\hline $\begin{array}{l}\text { Waist circumference } \\
\text { (inches) }\end{array}$ & $30.80 \pm 3.14$ & $31.50 \pm 3.02$ & $30.02 \pm 3.05$ & 0.0033 \\
\hline Hip circumference (inches) & $36.61 \pm 2.93$ & $37.15 \pm 2.44$ & $35.84 \pm 2.89$ & 0.0031 \\
\hline BMI (kg/m $)$ & $20.51 \pm 3.60$ & $20.86 \pm 3.77$ & $20.11 \pm 3.40$ & 0.2046 \\
\hline Waist-hip ratio & $0.84 \pm 0.05$ & $0.85 \pm 0.07$ & $0.86 \pm 0.06$ & 0.3518 \\
\hline Systolic BP(mm Hg) & $117.92 \pm 9.93$ & $119.60 \pm 10.81$ & $116.07 \pm 8.55$ & $<0.0001$ \\
\hline Diastolic BP(mm Hg) & $74.18 \pm 6.53$ & $75.07 \pm 6.84$ & $73.19 \pm 6.07$ & $<0.0001$ \\
\hline Total cholesterol (mg/dl) & $158.76 \pm 30.98$ & $148.95 \pm 27.09$ & $160.83 \pm 29.57$ & 0.0001 \\
\hline Trigyceride (mg/dl) & $89.73 \pm 38.02$ & $91.43 \pm 40.97$ & $83.97 \pm 26.82$ & $<0.0001$ \\
\hline $\begin{array}{l}\text { High density lipoproteins } \\
\text { (mg/dl) }\end{array}$ & $50.35 \pm 8.7$ & $50.22 \pm 10.00$ & $53.43 \pm 10.44$ & 0.0236 \\
\hline $\begin{array}{l}\text { Low density lipoproteins } \\
\text { (mg/dl) }\end{array}$ & $89.41 \pm 22.05$ & $88.07 \pm 20.18$ & $94.78 \pm 20.12$ & 0.0230 \\
\hline Fasting blood sugar (mg/dl) & $93.66 \pm 9.62$ & $94.77 \pm 10.1$ & $92.43 \pm 8.97$ & 0.6816 \\
\hline
\end{tabular}

The mean and S.D. of systolic BP between the males (119.60 \pm 10.81$)$ and females (116.07 \pm $8.55)$ with $\mathrm{p}<0.0001$ whereas diastolic BP between the males $(75.07 \pm 6.84)$ and females $(73.19 \pm$ 6.07) with $\mathrm{p}<0.0001$ was highly significant. (Table 3 ).

In the present study $02 \%$ male students had $\mathrm{BP} \geq 135 / 85$, which comes under prehypertension category.

WC and BMI were correlated with lipid profile and BP by Pearson's linear coefficient in Graph pad.

\section{Biochemical parameters}

When the lipid profile was compared, the mean and standard deviation (S.D.) of cholesterol in male students $(148.95 \pm 27.09)$ and female students $(160.83 \pm 29.57)$ with $\mathrm{p} 0.0001$, considered statistically significant. The mean and S.D. of triglyceride in male students $(91.43 \pm 40.97)$ and female students $(83.97 \pm 26.82)$ with $\mathrm{p}<0.0001$ statistically extremely significant. The $\mathrm{p}$ value for HDL and LDL between the male and female students was not statistically significant. (Table 3). But when abnormal lipid profile was compared between the male and female students, using chi square in graph pad, $2.5 \%$ males and $18.3 \%$ females had cholesterol more than $200 \mathrm{mg} / \mathrm{dl}$ with p 0.003 considered significant. (Table 4).

Table 4: Association of abnormal lipid profile with gender of the students

\begin{tabular}{|c|c|c|c|c|c|}
\hline \multirow[t]{2}{*}{ Lipid profile } & \multicolumn{2}{|c|}{$\begin{array}{c}\text { Males } \\
(n=79)\end{array}$} & \multicolumn{2}{|c|}{$\begin{array}{c}\text { Females } \\
(n=71)\end{array}$} & \multirow{2}{*}{$\begin{array}{c}\text { Statistical } \\
\text { significance } \\
\text { (p value) }\end{array}$} \\
\hline & $\begin{array}{c}\text { No. of } \\
\text { students }\end{array}$ & $\begin{array}{c}\text { Percentage } \\
(\%)\end{array}$ & $\begin{array}{c}\text { No. of } \\
\text { students }\end{array}$ & $\begin{array}{c}\text { Percentage } \\
(\%)\end{array}$ & \\
\hline $\begin{array}{l}\text { Total Cholesterol } \geq 200 \\
\mathrm{mg} / \mathrm{dl}\end{array}$ & 02 & 2.5 & 13 & 18.3 & 0.0032 \\
\hline Trigyceride $\geq 150 \mathrm{mg} / \mathrm{dl}$ & 07 & 8.8 & 01 & 1.4 & 0.32 \\
\hline $\begin{array}{l}\text { High density lipoproteins } \\
\leq 40 \mathrm{mg} / \mathrm{dl}\end{array}$ & 18 & 22.7 & 07 & 9.8) & 0.06 \\
\hline $\begin{array}{l}\text { Low density lipoproteins } \\
\geq 130 \mathrm{mg} / \mathrm{dl}\end{array}$ & 03 & 02 & 04 & 5.6 & 0.88 \\
\hline
\end{tabular}


Note: $\mathrm{p}$ value is for chi square test.

In the present study the mean and S.D. of FBS in male students $(94.77 \pm 10.1)$ and female students $\quad(92.43 \pm 8.97)$ with $\mathrm{p}<0.6816$ considered significant. In this study, $02(1.3 \%)$ had FBS >126 mg/dl, high risk of developing Type 2 diabetes mellitus. They had a family history of obesity, hypertension and diabetes mellitus.

When Total protein and Albumin was compared between the male and female students the value was in the normal range and was not of much statistical significance.

\section{Calculation of Risk factors}

The following were considered as risk factors: blood glucose of $\geq 126 \mathrm{mg} / \mathrm{dl}$, Total cholesterol of $\geq 200 \mathrm{mg} / \mathrm{dl}$, Triglyceride of $\geq 150 \mathrm{mg} / \mathrm{dl}, \mathrm{HDl}$ of $\leq 40 \mathrm{mg} / \mathrm{dl}, \mathrm{LDL} \geq 130 \mathrm{mg} / \mathrm{dl}$, BMI of $\geq 25$, WHR $>0.95$, and low physical activity (> $600 \mathrm{MET}$, min, wk-1). ${ }^{5}$

\section{Discussion}

Medicine is a highly paid and high status profession and medical students recognize that financial and social rewards place greater responsibilities on them, than for students who have yet to make a career choice ${ }^{6}$

The present study assessed the life style disorders, dietary habits of medical students, who represent a significant community of future practitioners. If the medical students are given proper guidance in early years and during medical schooling, could produce physicians practicing and promoting healthy diet and active life style. ${ }^{6}$

The results of the present study concluded that the overall prevalence of overweight and obesity among the students were $17.3 \%$ and $4 \%$ respectively, while $31.3 \%$ were underweight. A similar study by Ranjana Tiwari et $\mathrm{al}^{7}$ and P. Chhabra et $\mathrm{al}^{8}$ reported a prevalence of overweight $9.93 \%$ and $11.7 \%$ and prevalence of obesity $1.53 \%$ and $02 \%$, respectively. In their study it was noted that unreserved category had the maximum percentage of overweight and obesity in comparison to OBC, SC or ST respectively. Similarly the Hindus had a higher prevalence in comparison to Muslims, Sikhs and Christians respectively. The results are quiet lower than our study. A similar study by Kokila Selvaraj et $\mathrm{al}^{9}$ reported a prevalence of overweight $24.3 \%$ and obesity $8.6 \%$ which is higher compared to our study, Salient finding in their study is that $65 \%$ of the overweight and obese gave $\mathrm{H} / \mathrm{O}$ obesity of either or of both parents. This is almost similar to the fact that if one parent is obese there is $50 \%$ chance of children being obese. A similar study was conducted by Boo NY et $\mathrm{al}^{10}$ in Malaysia in private medical college \& found that $30.1 \%$ of the students were overweight or obese which was statistically higher than the present study findings.

Overweight was more prevalent among male students, while underweight was more common among female students. Most of the students were hostelites and overweight was due to less time for extracurricular activities due to frequent exams and vast medical syllabus, frequent visit to the restaurant (fond of junk food), maximum use of mobile and computers, even there was involvement of environmental and genetic factors. $38 \%$ female students were underweight since they are very choosy about the food and very much fond of packet foods and most of the time would skip the meals. By the time they reach clinical phase of their training, the students would have received reasonably adequate medical education on the prevention of and the adverse outcomes associated with overweight/obesity and underweight.

In the present study $03(3.7 \%)$ male students had blood pressure $\geq 135 / 85$, which comes under prehypertension category. Mostly, it was due to the vast medical syllabus, stress of the exams, no time for physical activities, fond spicy, oily, and packet food and also extra salt was used in the diet and some of them even had a family history of hypertension. Knowledge of aggressive control of hypertension can regress or reverse left ventricular hypertrophy and reduce the risk of cardiovascular disease in future, in the young medical students. (Harrison pg 2042)Among the prehypertensives, we found a favourable outcome for female students, probably due to the protective action of estrogen.

In a similar study by Amitabha Chattopadhyay et $\mathrm{al}^{11}$ concluded that, out of 850 students, $13.88 \%$ were hypertensive, while $19.18 \%$ were pre-hypertensive. In his study there was association of blood pressure with age, place of stay, gender, year of study and high WC and BMI along with frequent eating of fast food and lack of physical activity. In a similar study by Sunandha Senthil et al ${ }^{12}$ the incidence was $50 \%$, which showed relation between haemoglobin and systolic blood pressure. In a study done by Shobha et $\mathrm{al}^{13}$ incidence of prehypertension was $55.7 \%$ which showed a strong association of hypertension with high WC and BMI along with family history of diabetes mellitus in the study participants. A possible reason for the lower 
prevalence of prehypertension in our group could be due to small sample size as well as due to the lower prevalence of overweight among our students.

When the lipid profile was compared between the male and female students, cholesterol and triglyceride showed the $\mathrm{p}$ value (< 0.001) was highly significant (table 3) whereas when HDL-C and LDL-C was compared it was not statistically significant. When the abnormal lipid profile (cholesterol>200 mg/dl) was compared between the male and female students, $02(2.5 \%)$ males and $13(18.3 \%)$ females had cholesterol more than $200 \mathrm{mg} / \mathrm{dl}$ with $\mathrm{p} 0.003$ considered significant (Table 4). Many factors affect the cholesterol levels in blood. Some of them can be controlled and others cannot. We can control what we eat, our weight, and our level of activity. However, we cannot control heredity, age, or gender. The contributing factor for the high value of cholesterol among the female students may be environmental, genetic constitution, dietary habits and food habits, with preference for junk food, lack of physical activities/exercise, maximum use of technology like mobile phones, whatsapp and computers.

In the present study $50.63 \%$ males and $54.92 \%$ females students had FBS $>100 \mathrm{mg} / \mathrm{dl}$ low risk, whereas $6.32 \%$ males and $11.26 \%$ females had FBS $>110 \mathrm{mg} / \mathrm{dl}$ medium risk and $2.5 \%$ males and $1.4 \%$ females had FBS $>126$ $\mathrm{mg} / \mathrm{dl}$, high risk of developing Type 2 diabetes mellitus in future. Initially diabetes use to occur in $6^{\text {th }}$ or $7^{\text {th }}$ decade, than later it occurred in $4^{\text {th }}$ to $5^{\text {th }}$ decade, but nowadays diabetes occurs at a very younger age of 20-30 years i.e. $2^{\text {nd }}-3^{\text {rd }}$ decade. The students were overweight and had high waist circumference along with high cholesterol and triglyceride level, lack of physical activities and frequent visit to the restaurant. They also had a family history of diabetes mellitus, obesity and sedentary lifestyle as observed in the questionnaire.

In a similar study by $\mathrm{K} \mathrm{S}$ Achuth et $\mathrm{al}^{14}$ (2015) on the evaluation of Indian Diabetes Risk Score (IDRS), among the students, $52.1 \%$ were in low-risk category, $42.9 \%$ were in medium risk category, of which $71.6 \%$ were females, and $5.0 \%$ were in the high risk category, which is quiet high compared to the present study.

In the current study, the most frequent risk factors among the students were reduced HDLC, obesity, physical inactivity and elevated TG. The occurrence of undesirable blood lipid profile was also reported in Columbian students (low HDL-C $=13.3 \%$ ) by Feliciano-Alfonso JE et.al. ${ }^{15}$

In the present study when WC and BMI was correlated with lipid profile and blood pressure, only systoloic BP and TG showed positive correlation, while HDL-C showed negative correlation (Table 6).

Table 5: Comparisons of Biochemical variables between male and female students

\begin{tabular}{|c|l|c|c|c|c|}
\hline $\begin{array}{c}\text { S. } \\
\text { No. }\end{array}$ & \multicolumn{1}{|c|}{$\begin{array}{c}\text { Biochemical } \\
\text { Variables }\end{array}$} & $\begin{array}{c}\text { Biological } \\
\text { Reference } \\
\text { Interval }\end{array}$ & $\begin{array}{c}\text { Male } \\
\text { students } \\
(\mathbf{n}=\mathbf{7 9})\end{array}$ & $\begin{array}{c}\text { Female students } \\
(\mathbf{n = 7 1})\end{array}$ & $\begin{array}{c}\text { Statistical } \\
\text { significance } \\
\text { (p-value })\end{array}$ \\
\hline 1 & Total cholesterol & $120-200 \mathrm{mg} / \mathrm{dl}$ & $148.95 \pm 27.09$ & $160.83 \pm 29.57$ & 0.0001 \\
\hline 2 & Trigyceride & $40-150 \mathrm{mg} / \mathrm{dl}$ & $91.43 \pm 40.97$ & $83.97 \pm 26.82$ & $<0.0001$ \\
\hline 3 & $\begin{array}{l}\text { High density } \\
\text { lipoproteins }\end{array}$ & $30-50 \mathrm{mg} / \mathrm{dl}$ & $50.22 \pm 10.00$ & $53.43 \pm 10.44$ & 0.0236 \\
\hline 4 & $\begin{array}{l}\text { Low density } \\
\text { lipoproteins }\end{array}$ & $66-100 \mathrm{mg} / \mathrm{dl}$ & $88.07 \pm 20.18$ & $94.78 \pm 20.12$ & 0.0230 \\
\hline 5 & $\begin{array}{l}\text { Fasting blood } \\
\text { sugar }\end{array}$ & $70-110 \mathrm{mg} / \mathrm{dl}$ & $94.77 \pm 10.1$ & $92.43 \pm 8.97$ & 0.6816 \\
\hline 6 & Total protein & $6.4-8.3 \mathrm{~g} / \mathrm{dl}$ & $7.47 \pm 0.94$ & $7.56 \pm 0.42$ & 0.9850 \\
\hline 7 & Albumin & $3.5-5.2 \mathrm{~g} / \mathrm{dl}$ & $4.68 \pm 0.58$ & $4.62 \pm 0.30$ & 0.3927 \\
\hline
\end{tabular}

Note: Data expressed as Mean \pm SD. p value is for un-paired t- test.

Table 6: Correlation between anthropometric and biochemical parameters

\begin{tabular}{|l|c|c|}
\hline \multicolumn{1}{|c|}{ Parameters } & Correlation coefficient ( r) & P value \\
\hline Body Mass Index & $0.083(-0.24$ to 0.07$)$ & 0.31 \\
\hline Systolic Blood Pressure & $0.02(-0.13$ to 0.18$)$ & 0.78 \\
\hline Diastolic Blood Pressure & $0.05(-0.11$ to 0.20$)$ & 0.55 \\
\hline Total Cholesterol & $0.27(0.11$ to 0.41$)$ & 0.0008 \\
\hline Triglycerides & $-0.34(-0.47$ to -0.19$)$ & 0.0008 \\
\hline High Density Lipoproteins & $0.24(0.08$ to 0.38$)$ & 0.0032 \\
\hline Low Density Lipoproteins & \multicolumn{2}{|}{} \\
\hline Waist circumference &
\end{tabular}




\begin{tabular}{|l|c|c|}
\hline Systolic Blood Pressure & $-0.28(-0.42$ to -0.12$)$ & 0.0005 \\
\hline Diastolic Blood Pressure & $-0.11(-0.27$ to 0.04$)$ & 0.16 \\
\hline Total Cholesterol & $-0.07(-0.22$ to 0.09$)$ & 0.40 \\
\hline Triglycerides & $0.08(-0.07$ to 0.24$)$ & 0.28 \\
\hline High Density Lipoproteins & $-0.21(-0.36$ to -0.05$)$ & 0.008 \\
\hline Low Density Lipoproteins & $0.08(-0.07$ to 0.23$)$ & 0.316 \\
\hline
\end{tabular}

$\mathrm{P}$ value in bracket is $95 \%$ confidence interval.

Whereas other parameters of lipid profile did not show much significance with WC and BMI. In a similar study done by Simmy Kurian et.a ${ }^{16}$ and Deshmukh PR et $\mathrm{al}^{17}$ the $\mathrm{WC}$ and BMI showed a strong positive correlation with blood pressure. In the study by Vimal Gupta et $\mathrm{al}^{18}$ a significant positive correlation was seen between anthropometric indices (BMI, WC, WHtR) and diastolic blood pressure among study groups (Table 3) which is similar with the study done by Hazarika et al. ${ }^{19}$ It is also well accepted that different anthropometric indices like waist circumference, waist hip ratio, and BMI are equally good in predicting cardiovascular risk.[20] In the study by Prashant Vishwanath et $\mathrm{al}^{20}$ a positive correlation was seen when BMI, waist-hip ratio, and waist circumference was compared with total cholesterol, triglycerides, and LDL cholesterol. In his study alcohol consumption and smoking was positively correlated with abnormal lipid profile indicating dyslipidemia in them and possible future risk of cardiovascular events. In our study none of the students were smokers and alcoholics. Thus anthropometric parameters can be used as a screening test for predicting future cardiovascular risk. An increase in total cholesterol, LDL cholesterol, and triglycerides in overweight and obese individuals also supports the view that a simple calculation of BMI can act as a screening indicator of the future risk of cardiovascular or other ischemic complications. These anthropometric parameters can be easily modified by physical activity, participation in sports, healthy diet, yoga as well as meditation.

World Health Organization recommends measurement of the BMI as a universal criterion of overweight $(\geq 25)$ and obesity $(\geq 30)$ while measures of abdominal fat distribution such as WC or waist-to-hip ratio (WHR) are also advised. There is evidence to support the use of BMI in risk assessment since it provides a more accurate measure of total body fat compared with the assessment of body weight alone. BMI does not however, distinguish fat from muscle. Excess abdominal fat is an important, independent risk factor for disease.

\section{Conclusion}

As overweight, obesity, hypertension, hyperlipidaemia and hyperglycemia along with a high waist measurement and a high BMI serve as good indicators in recognizing cases at high risk that might progress to cardiovascular and metabolic disorders in later period of life. Students with abnormal FBS, lipid level and hypertension were referred to the Physician. All the students were given advice regarding healthy lifestyle practices.

Hence by conducting educational programs, regarding healthy lifestyle, recreational activities, yoga meditation and providing good and nutritious food in the campus canteen and follow up of students with lifestyle disorders would be beneficial. In Government Medical College, Bhavnagar with the help of our respected Dean Sir, every Wednesday we follow, "NO PETROL DAY" and it is compulsory for the students as well as the faculties to use bicycle or reach the campus by walking. In our college canteen of GMC, cleanliness is maintained, nutritious food is served and instead of coco cola, thumps up, students are served fresh fruit juices. This helps to keep the health care fraternity in better shape. Healthy lifestyles should be adopted from young adulthood itself as these medical students are pillars of future Nation.

\section{Acknowledgment}

We are thankful to ${ }^{\mathrm{It}} \mathrm{MBBS}$ students of batch 2014-2015 of GMC, Bhavnagar, Gujarat, who took part in the study and our respected Dean Sir, Dr C. B. Tripathi, for their assistance during the study and Dr H.O Sharma, Professor and Head.

\section{Conflicts of interest}

To keep the future Doctors healthy.

\section{References}

1. Dr. Lavina Sinha, Prehypertension, Heart rate, Obesity and their co-relation; Survey on Medical Students. Gujarat medical journal / july-2015 Vol. 70 No.2.

2. Hanan Abo-Elgamelen Ebrahim Essa, and Monera Bassuny Abdalla El-Shemy, Prevalence 
of lifestyle associated risk factors for noncommunicable diseases and its effect on quality of life among nursing students, faculty of nursing, Tanta University, International Journal of Advanced Research (2015), Volume 3, Issue 5,429-46.

3. Sharma R, Mandliya J, Dhaneria M, Tiwari H L, Prevalence of hypertension in mid adolescents in central India: A school based comparative study. International Journal of Medical Research and Review, September, 2015, Vol 3, Issue.

4. Dragana Pap, Emina olak, Nada Majki-Singh, Gordana Grubor-Laj, Sanja Vickovi. Lipoproteins and other risk factors for cardiovascular disease in a student population. J Med Biochem 2013;32(2).

5. Mohammad Y. Gharaibeha, e, Karem H Alzoubib, Omar F. Khaboura, Lubna Tinawia, Rawan Hamada, Esraa F. Keewanc, Sulaiman K. Matarnehb, Mahmoud A. Alomarid, Assessment of Cardiovascular Risk Factors Among University Students: The Gender Factor, Cardiol Res, 2012;3(4):172-9.

6. Ross A Hammond, Ruth Levine. The economic impact of obesity in the United States. Journal of Diabetes, Metabolic Syndrome and Obesity: Targets and Therapy 2010:3 285-95. Targets and Therapy Dove press.

7. Ranjana Tiwari,VikasJain,Ajit Singh Rajput,A. K. Bhagwat, Manish Goyal, Sakshi Tiwari. A study to assess prevalence of obesity among medical students of G.R. medical college, Gwalior, M. P., India.International Journal of Research in Medical Sciences. OctoberDecember 2014, Vol 2, Issue 4 Page 1412.

8. P. Chhabra, V. L. Grover, K. Aggarwal, A.T. Kannan. Nutritional Status and Blood Pressure of Medical Students in Delhi. Indian Journal of Community Medicine Vol. 31, No. 4, OctoberDecember, 2006.

9. Kokila Selvaraj, P.Sivaprakasam. A Study on the Prevalence of Overweight and Obesity among Medical Students of Kanchipuram District. National Journal of Research in Community Medicine. Vol. 2. Issue 2. July-Sep. 2013 (079148).

10. Boo NY, Chia GJ, Wong LC, Chew RM, Chong W, et al. (2010) The prevalence of obesity among clinical students in a Malaysian medical school. Singapore Med J 51:126-32.

11. Amitabha Chattopadhyay, Pranita Taraphdar, Badal KumarSahu, Sanghamitra Maulik,Ghosh,Abhik Sinha, Mallika Biswas. A study on prevalence of Hypertension and its related risk factors among undergraduate medical students in Kolkata. IOSR Journal of Dental and Medical Sciences (IOSR-JDMS). Volume 13, Issue 11 Ver. V (Nov. 2014), PP 01-7.

12. Sunandha Senthil, Subbalakshmi Naasajjana Krishndasa. Pre-Hypertension in Apparently Healthy Young Adults: Incidence and Influence of Haemoglobin Level. Journal of Clinical and Diagnostic Research. 2015 Nov, Vol9(11):CC10-CC1210.

13. Shobha S Shetty, Avinash Nayak. Prevalence of prehypertension amongst medical students in coastal Karnataka. Journal of Evolution of
Medical and Dental Sciences.Volume 1, Issue 6, December-2012

14. K S Achuth, S Mangala, C Pradeep, J Mini, G Subrahmanyam. Risk of Type 2 Diabetes Mellitus in Adolescents in a Medical College in Bangalore, India. International Journal of Scientific Study. July 2015, Vol 3, Issue 4.

15. Feliciano-Alfonso JE, Mendivil CO, Ariza ID, Perez CE. Cardiovascular risk factors and metabolic syndrome in a population of young students from the National University of Colombia. Rev Assoc Med Bras. 2010;56(3):293:8.

16. Simmy Kurian, Manjula V.D., Annamma, Jaimol Zakariah. A study on cardio vascular risk factor profile of medical students in a tertiary care hospital of central kerala, National Journal of Medical Research |Volume 5 | Issue 1 | Jan March 2015

17. Deshmukh PR, Gupta SS, Dongre AR, Bharambe MS, Maliye C, Kaur S etal. Relatioship of anthropometric indicators with blood pressure levels in rural Wardha. Indian J Med Res. 2006 May;123(5):657-64.

18. Vimal Gupta, Reena Singla , Minu Bedi. Correlation of anthropometric parameters with blood pressure: an anthropometric study in north indian haryanavi male, Int J Anat Res 2016, 4(2):2485-9. ISSN 2321-4287.

19. Hazarika NC, Narian K, Biswas D, Kalia HC, Mahanta J. Hypertension in the native rural population of Assam. Natl Med J Ind.2004;17:300-4.

20. Prashant Vishwanath, Akila Prashant, Anand Acharya, Suma MN, Kiran HS1, Karthik G, Use of anthropometric indices as simple predictors of deranged lipid profile and at risk population for future cardiovascular events, International Journal of Health \& Allied Sciences, Vol. 1, Issue 1, JanMar 2012. 